\title{
Climate Adaptation and Job Prospects for Young People in Agriculture
}

\section{Nicola Cenacchi, Karen Brooks, Shahnila Dunston, Keith Wiebe, Channing Arndt, Faaiqa Hartley, and Richard Robertson}

According to the United Nations, the world's population will grow by 2 billion people over the coming decades to reach 9.7 billion by 2050 (UNDESA-DP 2019a). The dignity and life prospects of those additional 2 billion people will depend on their ability to meet basic needs, such as food, clothing, and shelter, and their access to adequate employment. The most pressing need for jobs will be felt in those regions and countries that have not yet gone through the demographic transition, ${ }^{1}$ and where the cohort of young people is growing rapidly. The challenge will be compounded by an increasingly crowded, more competitive world with fewer natural resources per capita, and by the threat of climate change, which is projected to affect every sector of the economy (Arent 2014).

Different countries and regions will face challenges of varying magnitudes depending on their economic and demographic outlook and their exposure to climate change impacts. In some places, the intersection of climate resilience and employment prospects will be especially salient. Where the population is growing and the economy is still highly reliant on agriculture, rural youth will look to the agriculture sector for both food security and job security. These demands will not be met without strategic and targeted investments in climate change adaptation.

Young people are vitally important for the economy and for rural development in particular. Youth is a time of transition toward independence during which key decisions are made; the success of this transition is crucial both for individuals' future well-being and for the social and economic prospects of their societies. Yet growth in the youth population also poses challenges. Nearly 1 billion of the world's 1.2 billion young people (between ages 15 and 24) reside in developing countries, and their numbers are growing faster there than in high-income countries. Young people represent the largest share of the rural population in all developing countries, and youth growth

\footnotetext{
1 "Demographic transition" refers to the transition from high birth and death rates to lower ones. Because the decline in birth rates comes later than the decline in death rates, countries go through a period during which they have increasingly young and rapidly growing populations.
} 
is concentrated in low-income countries with high poverty rates, especially in Africa south of the Sahara and Asia (IFAD 2019a). By virtue of their age, it will be today's youth, more than any other group, who suffer from the failure to implement climate change adaptation and mitigation strategies.

Therefore, climate change is foremost a youth issue. It is specifically an issue for youth employment because in most developing countries with a large youth share, jobs and economic growth depend heavily on agriculture, a sector expected to be strongly affected by climate change, through both direct impacts on crop and livestock productivity and indirect impacts on infrastructure and other sectors. Rural youth are also likely to be more sensitive to climate impacts because they tend to have low skills, low social capital, and low integration and participation in the community (Adger 2003). This also makes them less likely to have access to credit and insurance, which lowers their adaptive capacity. The vulnerability of rural young people to climate change in terms of employment prospects is thus a function both of their stage in life and of the vulnerability to climate change of agriculture, the sector that in all likelihood will have to absorb the greatest share of youth into its workforce. A better understanding of the intersection/interplay between climate resilience and youth employment, and where it may be stronger geographically, is therefore necessary to generate better policy and adaptation options for the future of agriculture and of young people.

\section{Agriculture will need to employ a growing rural youth population, especially in Africa south of the Sahara}

Demographic projections show that regional conditions vary widely. For example, East Asia and South Asia have some of the largest numbers of rural youth, ${ }^{2}$ but both regions are undergoing a demographic transition characterized by falling family sizes and declining numbers of young people in rural areas, which is expected to continue over the next several decades (UNDESA-PD 2019b). Moreover, the economies of these two regions are quickly urbanizing, and they are well into the process of structural transformation ${ }^{3}$ and diversification, supported by investments in infrastructure and human capital.

As economies diversify, the agricultural labor force is expected to decline as a share of the total labor force; and in the middle-to-advanced phases of the process, the absolute number of people employed in agriculture also drops (McMillan, Rodrik, and Sepulveda 2017). This decline in absolute numbers can already be observed in East Asia and South Asia, as more people move out of agriculture and take jobs in manufacturing, services, and other nonagricultural sectors (ILOSTAT 2019). As the impact of climate change intensifies, youth across these two regions will be affected. But their rapidly diversifying economies will provide a spectrum of job opportunities for young people to choose from - some more and some less affected by climate change.

In other parts of the world, particularly in Africa south of the Sahara (SSA), conditions are different. Currently, there are around 130 million young rural people in SSA. According to projections, this demographic group will continue to rise until about $2045^{4}$ and will then slowly decline as family sizes fall and the demographic transition kicks in. Most SSA countries still depend on agriculture; ${ }^{5}$ structural transformation is ongoing but proceeding at a slow pace, and employment in agriculture is growing even as its share of the labor force declines (Figure 1). ${ }^{6}$ Agricultural production and associated value chains are expected to continue being a major employer of young people in the region until 2050.

\footnotetext{
2 By young people, we mean those between the ages of 15 and 24 . The definition applies throughout this brief. The estimated rural youth population in 2020 is about 120 million in East Asia and 220 million in South Asia. This was estimated based on the difference between total and urban population data (UNDESA-PD 2017).

3 "Structural transformation" is the term used to indicate a process of economic transition from large dependence on agriculture to diversification toward inclusion of manufacturing and service jobs, with all the associated shifts in the composition of the labor force. ${ }^{4}$ Projections show that the rural population in all other regions will decline through to 2050 (UNDESA-PD 2017).

${ }^{5}$ According to the World Bank's World Development Indicators (accessed on June 3, 2020), agriculture's share of GDP in SSA is over 20 percent, and its share in employment is more than 50 percent.

${ }^{6}$ This phenomenon is not unusual for countries going through the structural transformation process. China is an example. From 1978 to 1990 , the country was going through its structural transformation and yet the agricultural labor force was increasing.
} 
Figure 1. Agriculture's share of GDP in 2016 vs. projected youth share of the population in 2030

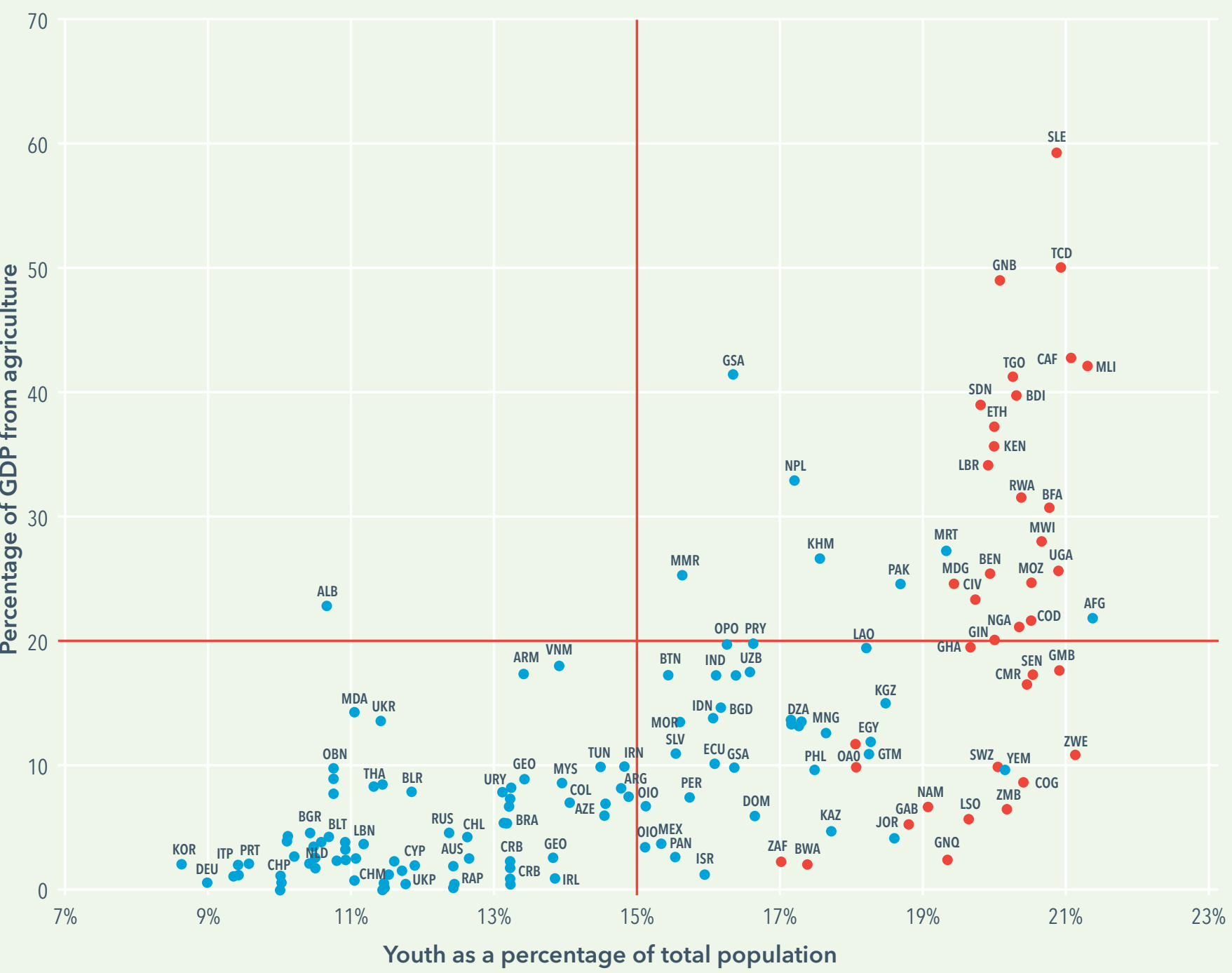

Sources: Authors. GDP data are from World Bank World Development Indicators (accessed 2018). 2030 data for youth are from the SSP Database (IIASA 2013; O'Neill et al. 2014).

Note: Red dots = SSA countries; blue dots = rest of the world. The blue cluster in the lower left includes countries that (1) already completed the demographic transition and have an aging population (lower share of youth in the total population); and (2) are less dependent on agriculture for employment and economic growth. The group of countries in the upper right quadrant are countries, mostly in SSA, with younger populations and a greater dependence on agriculture. The red dots in the lower right include some resource-rich African countries where agriculture is a large employer despite not being a large share of total GDP. The 15 percent benchmark on the $X$ axis represents the approximate midpoint in the range of values observed across countries. The 20 percent benchmark on the $Y$ axis identifies a transition point above which the economy is considered to have a medium to high reliance on agriculture (IFAD 2019; Brooks et al. 2019).

Why is structural transformation in SSA countries expected to be slow? Why are the region's economies not diversifying and rapidly adding jobs to the manufacturing and service sectors? The are several reasons. First, the current international environment for structural transformation is different from that of the 20th century. The global economy is changing; with more mechanization and automation than in the past, growth is now focused on less labor-intensive jobs, thereby slowing the pace at which certain jobs can be created. Job growth will be relatively low 
in labor-intensive sectors such as manufacturing, which is most relevant to the SSA context. Second, job growth in the high-tech sector is likely to benefit SSA at a slower pace because many countries across the region are still held back by weak fundamentals, including poor infrastructure and low investment in education and human capital (McMillan, Rodrik, and Sepulveda 2017).

The third factor has to do with food and commodity prices. Most economic models project that population and income growth will push up food prices in the coming decades, especially when the impacts of climate change are considered. This is very different from the 20th century, when real food prices trended downward almost continuously, despite occasional price spikes. In the short term, net sellers of food will gain while net consumers suffer.

As time passes, the composite effects of higher food prices may slow the rate of structural transformation with a potential dampening effect on economic growth. This is because higher food prices encourage greater production of food and therefore also retaining labor and capital in food production. This retention of productive resources in food slows the movement of labor and capital toward production of manufactures and (high productivity) services.

If climate change and other factors slow the rate of technical progress in food production relative to manufactures and services, the retention of labor and capital in food production slows the rate of technical change in aggregate, leading to lower economic growth overall and a slower development process. This also suggests that if a country were able to take advantage of the shift in economic activity toward agriculture, investments in the sector aimed at capturing growing markets could lead to technical innovation, mechanization, and release of labor, thus helping to drive the economic transformation.

If structural transformation in African countries proceeds at a slower pace than was experienced by other countries and regions in the 20th century, agriculture must play an important role in absorbing a growing young, rural labor force, as well as in improving welfare and incomes. For this to happen, the first condition is a shared understanding that agriculture must be part of a short-, medium-, and long-term labor strategy, and that investments in agricultural science and technology are necessary to strengthen the sector. If productivity improves and output grows faster than the total labor force, then farming becomes a better option for those who remain in agriculture, and the agriculture sector overall will be able to release labor to manufacturing and services. However, few African governments have shown meaningful recognition of just how important agriculture is as a source of job opportunities for young people, and current investments are lower than they should be (Beintema and Stads 2017).

Crucially, agriculture will not thrive and deliver on significant productivity improvements without adaptation to climate change. This is especially true because the countries where structural transformation is slow and the rural youth population is growing are also the countries where agriculture is projected to be severely hit by changes in temperature and precipitation and in the frequency of extreme weather events.

\section{Young countries that rely on agriculture are highly exposed to climate change}

Climate change is very likely to produce negative global impacts on crop and livestock productivity, including under those scenarios that are close to the current emissions pathways, even considering all the uncertainties in simulations (Nelson et al. 2014; Challinor et al. 2014; Rosenzweig et al. 2014). If we plot the world's countries according to their proportion of youth population and projected change in heat stress in 2050, we see that countries with a high youth share are also likely to experience extreme heat (Figure 2). Many of these countries are in SSA and are also dependent on agriculture. Climate change is therefore likely to impose additional stress on countries that are both young and undergoing a slow structural transformation toward a more diversified economy. 
Figure 2. Proportion of youth population and additional days of extreme heat by country, 2050

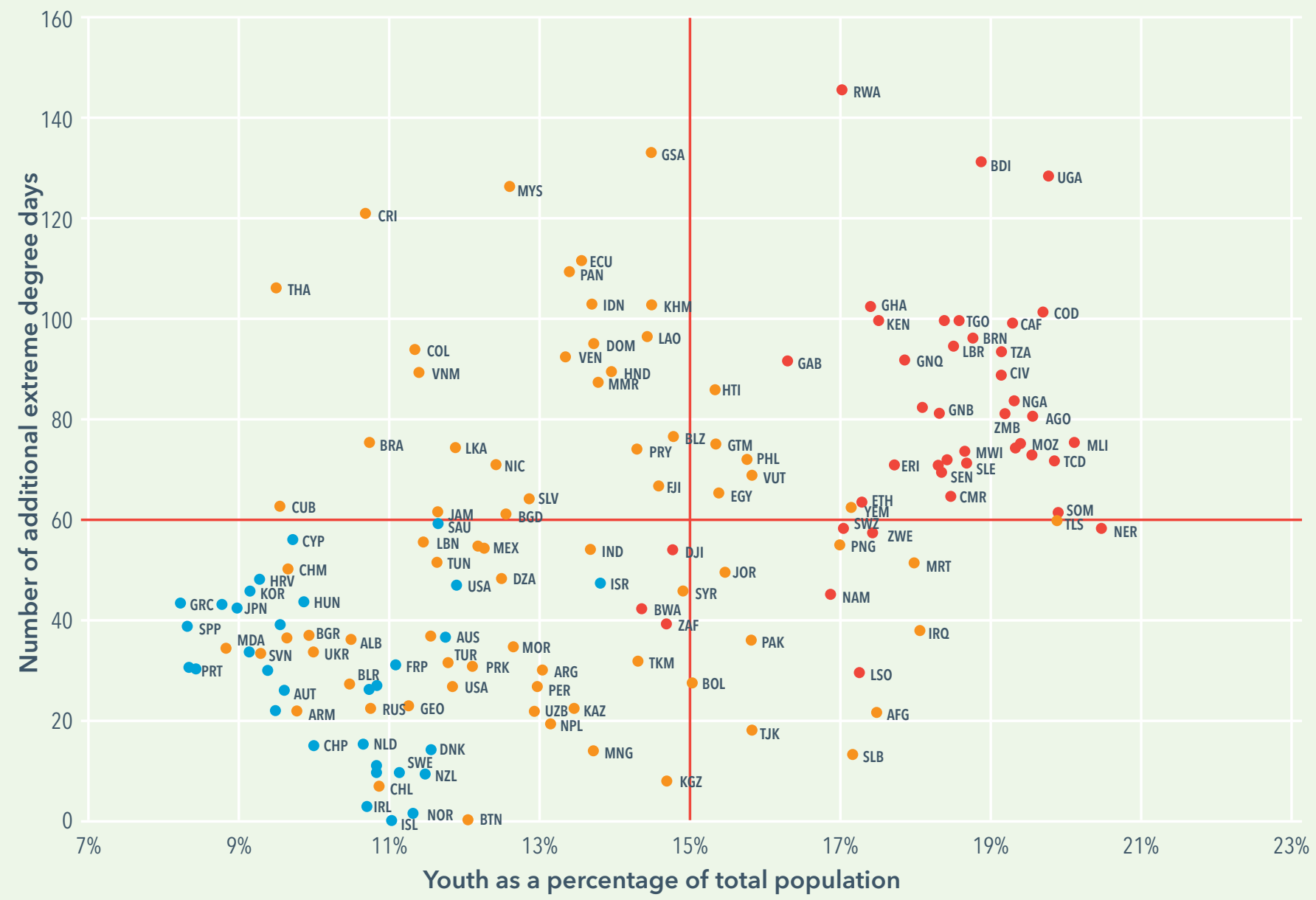

Sources: Authors. GDP data are from World Bank World Development Indicators (accessed 2018). 2050 data for youth are from the SSP Database (IIASA 2013).

Note: Blue dots = high-income countries; orange dots = low- and middle-income countries outside of SSA; red dots = SSA countries. The number of additional days (on top of today) of extreme heat is calculated as a combination of temperature and humidity that make it difficult to work, stressful for livestock, and damaging to crops yields (Robertson 2016). The 15 percent benchmark on the $X$ axis represents the approximate midpoint in the range of values observed across countries. The 60-day point on the $Y$ axis is highlighted because most of the countries whose youth share is over 15 or 17 percent are projected to have more than 60 additional days of heat stress (number of extreme degree days) in 2050 (IFAD 2019b).

As climate change sets in and effects on both crop yields and livestock become more severe, prices are expected to rise beyond what is projected in a scenario without climate change. As farmers try to take advantage of higher commodity prices, more labor and capital are diverted toward the agriculture sector. In fact, model results show that in most countries the higher prices more than offset the revenue impact of yield losses due to climate change, and most countries are expected to see an increase in gross agricultural revenues, at least until 2050. The potential increase in revenues may continue driving the importance of agriculture, not only as a source of food but also as a source of employment.

However, this does not imply that climate change impacts are positive. This calculation of revenues does not consider increased costs, including the long-term costs of the larger health and disease burden expected to result from increased food and nutrition insecurity (Springmann et al. 2016; Beach et al. 2019; Myers et al. 2015). In addition, the damage to yields may be larger than we anticipate, especially considering the impact of increased variability and extreme events, which are not captured in most global analyses. Moreover, as noted above, higher prices are likely to delay the 
economic transition toward manufacturing and services and dampen economic growth (Brooks 2018). And as prices rise, so does the value of land, which young people may then be less likely to be able to afford.

Another potential hidden cost related to climate impacts is that of differential adaptation. Large global producers, such as high-income countries in the temperate zones, may be able to adapt faster than poorer and harder-hit countries and recover at least some of their yield losses and production. Large producers affect global trade and prices; fast adaptation on their part may limit the global impact on supply and ease price increases. Should this happen, poorer countries would still be exposed to yield reduction, but without the benefits of higher crop prices to float revenues and offset the damages. This will limit the ability of the agriculture sector to employ the growing rural youth population in those countries.

The magnitude of projected impacts and associated uncertainty means that in many countries, agriculture will not be able to provide both food security and jobs for young people without large investments in adaptation. Adaptation is critical to allow farms to employ people, to reduce yield losses and yield variability, to contain the increase in commodity prices, and thereby to allow the economy to continue on its development path. Investments in agricultural science and technology are key to achieving this goal. Collaborative studies across the CGIAR have shown that technologies and practices consistent with sustainable intensification help to build the resilience of agroecosystems by conserving the natural resource base and may limit the negative impact of climate change on yields and even offset the impacts for some crops and regions (Rosegrant et al. 2014; Islam et al. 2016; Godfray et al. 2010; Robinson et al. 2015). More studies have simulated the regional and global adaptation and mitigation effects of wide adoption of climate-smart agriculture (de Pinto et al. 2017) and explored the overall benefits and trade-offs originating from a broad range of increased investments in agriculture, including in research and development, infrastructure, and water management (Rosegrant et al. 2017).

\section{Improved fundamentals, science, and markets for high-value products will support employment of rural youth in agriculture}

What type of policy agenda can successfully safeguard agriculture against the adverse effects of climate change and make the sector an attractive and effective source of jobs and opportunities for young people? Achieving these aims will require an agenda that focuses on boosting the resilience of the agriculture sector, that recognizes where market opportunities lie, and that tackles these challenges by tapping into the growing pool of youth labor.

Opportunities for adaptation differ by region and locality. Progress anywhere, however, requires continued investments in agricultural science, especially in sustainable agriculture and climate-smart options. Yet many of the countries that will be relying on a strong agriculture sector for economic growth and job opportunities are at present underinvesting in agriculture, especially in SSA (ASTI 2018). Studies on barriers to adoption of sustainable intensification or climate-smart technologies do not clarify whether youth has a particular role in either enabling the adoption of or benefiting from these technologies. However, the literature does show that land tenure and access to information are instrumental for their adoption. Young people are likely to be lacking both; therefore, tackling issues around land tenure and information will make it more likely that young people entering agriculture will adopt these technologies.

In general, investments in education, infrastructure, and telecommunications create the fundamental conditions for development in agriculture and other sectors. For agriculture, a number of complementary investments are needed to strengthen provision of information (for example, on weather, climate, production, and prices), agricultural science, the release of new crop varieties, water resource management, and management approaches that safeguard ecosystem services. Job creation will also rely increasingly on access to market knowledge and generation of opportunities around processing and high-value products, in addition to primary production. 
Young people entering the labor market must do so with adequate human capital. A strong general education (that is, training people to be able to learn) is more important than vocational education centered on specific skills, although the latter can be useful if closely tied to job opportunities. Access to reproductive health services, land tenure security and transparency in land transactions, and knowledge of risk management and basic finance are also important to equip young women and men for futures in agriculture, whether on or off the farm.

\section{Conclusions}

In the coming years, the difference between poverty and a course toward prosperity will depend on successful agricultural adaptation to climate change. Low-income, agriculture-dependent countries with rapidly growing cohorts of young people needing jobs must make significant investments in agricultural science and technology, rural infrastructure, and human capital to generate employment and adapt to climate change. Only if agricultural productivity and output grow rapidly can agriculture-dependent countries outpace the downward pressure that climate change and a growing labor force will exert on wages and earnings. Depending on the magnitude of local climate impacts, higher prices may offer economic opportunities for those farmers who have access to resources, information, and technology; while a workforce abounding in young people may offer potential in terms of technology and innovation, without adequate support for those young workers, it may still be one that is disadvantaged in terms of adaptive capacity.

Success is therefore not a given. It hinges on the realization of the role that agriculture will have to play and a willingness of policymakers to commit to investments and reforms. The number of young job seekers is already high and continues to grow. Considering the time lag in reaping the benefits of agricultural research, the time to act is now.

This work was funded by the CGIAR Research Program on Policies, Institutions, and Markets (PIM), led by the International Food Policy Research Institute (IFPRI), and by the CGIAR Research Program on Climate Change, Agriculture and Food Security (CCAFS). This publication has been peer reviewed. Any opinions stated in this brief are those of the authors and are not necessarily representative of or endorsed by IFPRI, PIM, CCFAS, or the University of Cape Town.

Nicola Cenacchi and Shahnila Dunston are senior research analysts, Keith Wiebe is a senior research fellow, Richard Robertson is a research fellow, and Channing Arndt is the director of the Environment and Production Technology Division (EPTD) at IFPRI, Washington, DC, USA; Karen Brooks is the former director of the CGIAR Research Program on Policies, Institutions, and Markets (PIM); and Faaiqa Hartley is an economist at the University of Cape Town's Economic Research Centre, South Africa.

\section{INTERNATIONAL FOOD POLICY RESEARCH INSTITUTE A world free of hunger and malnutrition IFPRI is a CGIAR Research Center}

1201 Eye St, NW, Washington, DC 20005 USA | T. +1-202-862-5600 | F. +1-202-862-5606 | Email: ifpri@cgiar.org | www.ifpri.org | www.ifpri.info DOI: https://doi.org/10.2499/9780896293892 


\section{References}

Adger, W.N. 2003. "Social Capital, Collective Action, and Adaptation to Climate Change." Economic Geography 79, no. 4: 387-404.

Arent, D.J., R.S.J. Tol, E. Faust, J.P. Hella, S. Kumar, K.M. Strzepek, F.L. Tóth, and D. Yan. 2014. "Key Economic Sectors and Services." In Climate Change 2014: Impacts, Adaptation, and Vulnerability. Part A: Global and Sectoral Aspects. Contribution of Working Group II to the Fifth Assessment Report of the Intergovernmental Panel on Climate Change, edited by C.B. Field et al. 659-708. Cambridge and New York: Cambridge University Press.

ASTI. 2018 Agricultural Science and Technology Indicators. Available at https://www.asti.cgiar.org.

Beach, R.H., T.B. Sulser, A. Crimmins, N. Cenacchi, J. Cole, N.K. Fukagawa, D. Mason-D'Croz, S. Myers, M.C. Sarofim, M. Smith, and L.H. Ziska. 2019. "Combining the Effects of Increased Atmospheric Carbon Dioxide on Protein, Iron, and Zinc Availability and Projected Climate Change on Global Diets: A Modelling Study." Lancet Planetary Health 3, no. 7 (July): e307-e317.

Beintema, N. and G.-J Stads. 2017. A Comprehensive Overview of Investments and Human Resource Capacity in African Agricultural Research. ASTI Synthesis Report. Washington, DC: International Food Policy Research Institute (IFPRI).

Brooks, K., Shahnila Dunston, Keith Wiebe, Channing Arndt, Faaiqa Hartley, and Richard Robertson. Climate and Jobs for Rural Young People. 2019. In Papers of the 2019 Rural Development Report. IFAD Research Series. London: International Fund for Agricultural Development.

Challinor, A., J. Watson, D. Lobell, et al. 2014. "A Meta-Analysis of Crop Yield under Climate Change and Adaptation." Nature Climate Change 4, no. 4: 287-291.

De Pinto, A., H.-Y. Kwon, N. Cenacchi, and S. Dunston. 2017. "The Effects of Widespread Adoption of Climate-Smart Agriculture in Africa South of the Sahara under Changing Climate Regimes." In A Thriving Agricultural Sector in a Changing Climate: Meeting Malabo Declaration Goals through Climate-Smart Agriculture, edited by A. De Pinto and J.M. Ulimwengu. Washington, DC: IFPRI.

Godfray, H. C. J., J.R. Beddington, I.R. Crute, L. Haddad, D. Lawrence, J.F. Muir, J. Pretty, S. Robinson, S.M. Thomas, and C. Toulmin. 2010. "Food Security: The Challenge of Feeding 9 Billion People." Science 327, no. 5967: 812-818.

IFAD (International Fund for Agricultural Development). 2019a. 2019 Rural Development Report - Creating Opportunities for Rural Youth. Rome: IFAD.

IFAD. 2019b. "Climate Change Is a Youth Issue." In 2019 Rural Development Report - Creating Opportunities for Rural Youth. Rome: IFAD.

IIASA (International Institute for Applied Systems Analysis). 2013. Shared Socioeconomic Pathways (SSP) Database.

ILOSTAT (International Labour Organization). 2019. ILO Modelled Estimates, Employment by Sector. Available at https://ilostat.ilo.org/data/excel-tools/.

Islam, S., N. Cenacchia, T.B. Sulser, S. Gbegbelegbe, G. Hareau, U. Kleinwechter, D. Mason-D'Croz, S. Nedumaran, R. Robertson, S. Robinson, and K. Wiebe. 2016 "Structural Approaches to Modeling the Impact of Climate Change and Adaptation Technologies on Crop Yields and Food Security. Global Food Security 10 (September): 63-70.

McMillan, M.S., D. Rodrik, and C. Sepulveda. 2017. Structural Change, Fundamentals and Growth: A Framework and Case Studies. Washington, DC: IFPRI. 
Myers, S.S., K.R. Wessells, I. Kloog, A. Zanobetti, and J. Schwartz. 2015. "Effect of Increased Concentrations of Atmospheric Carbon Dioxide on the Global Threat of Zinc Deficiency: A Modelling Study." Lancet Global Health 3, no. 10: e639-e645.

Nelson, G.C., H. Valin, R.D. Sands, P. Havlík, H. Ahammad, D. Deryng, J. Elliott, S. Fujimori, T. Hasegawa, E. Heyhoe, P. Kyle, M. Von Lampe, H. Lotze-Campen, D. Mason d'Croz, H. van Meijl, D. van der Mensbrugghe, C. Müller, A. Popp, R. Robertson, S. Robinson, E. Schmid, C. Schmitz, A. Tabeau, and D. Willenbockel. 2014. "Climate Change Effects on Agriculture: Economic Responses to Biophysical Shocks." PNAS 111, no. 9: 3274-3279.

O'Neill, B.C., E. Kriegler, K. Riahi, K.L. Ebi, S. Hallegatte, T.R. Carter, R. Mathur, and D.P. van Vuuren. 2014. "A New Scenario Framework for Climate Change Research: The Concept of Shared Socioeconomic Pathways." Climatic Change 122 (February): 387-400.

Robertson, R. 2016. "Heat Stress Could Be a Problem for Livestock Living Outdoors under Climate Change." December 21. IFPRI Climate Change. Available at https://climatechange.ifpri.info/heat-stress-could-be-a-problem-for-livestockliving-outdoors-under-climate-change/.

Robinson, S., D. Mason-D'Croz, S. Islam, N. Cenacchi, B. Creamer, A. Gueneau, G. Hareau, et al. 2015. “Ex Ante Analysis of Promising and Alternative Crop Technologies Using DSSAT and IMPACT." IFPRI Discussion Paper 01469. IFPRI: Washington, DC.

Rosegrant, M.W., J. Koo, N. Cenacchi, C. Ringler, R.D. Robertson, M. Fisher, C.M. Cox, K. Garrett, N.D. Perez, and P. Sabbagh. 2014. Food Security in a World of Natural Resource Scarcity: The Role of Agricultural Technologies. Washington, DC: IFPRI.

Rosegrant, M.W, T.B. Sulser, D. Mason-D'Croz, N. Cenacchi, A. Nin-Pratt, S. Dunston, T. Zhu, C. Ringler, K.D. Wiebe, S. Robinson, D. Willenbockel, H. Xie, H.-Y. Kwon, T. Johnson, T.S. Thomas, F. Wimmer, R. Schaldach, G.C. Nelson, and B. Willaarts. 2017. Quantitative Foresight Modeling to Inform the CGIAR Research Portfolio. Washington, DC: IFPRI.

Rosenzweig, C., J. Elliott, D. Deryng, A.C. Ruane, C. Müller, A. Arneth, K.J. Boote, C. Folberth, M. Glotter, N. Khabarov, K. Neumann, F. Piontek, T.A.M. Pugh, E. Schmid, E. Stehfest, H. Yang, and J.W. Jones. 2014. "Assessing Agricultural Risks of Climate Change in the 21st Century in a Global Gridded Crop Model Intercomparison." PNAS 111, no. 9: 3268-73.

Springmann, M., D. Mason-D'Croz, S. Robinson, T. Garnett, H.C.J. Godfray, D. Gollin, M. Rayner, and P. Ballon, P. Scarborough. 2016. "Global and Regional Health Effects of Future Food Production under Climate Change: A Modelling Study." Lancet 387, no. 10031: 1937-1946.

UNDESA-PD (UN Department of Economic and Social Affairs-Population Division). 2017. World Population Prospects. New York: United Nations.

UNDESA-PD. 2019a. World Population Prospects 2019: Highlights. New York: United Nations.

UNDESA-PD. 2019b. World Population Prospects 2019, Volume I: Comprehensive Tables. New York: United Nations.

World Bank. 2018. World Development Indicators. Available at https://databank.worldbank.org/source/worlddevelopment-indicators. 